\title{
Comment on "Burrough, S.E., Breman, E., and Dodd, C., 2012. Can phytoliths provide an insight into past vegetation of the Middle Kalahari paleolakes during the late Quaternary? Journal of Arid Environments 82, 156-164"
}

\author{
A B S T R A C T
}

Keywords:

Botswana

Grasses

Kalahari

Phytoliths

Quaternary

Vegetation

\begin{abstract}
This is a comment on the article of Burrough et al. (2012) in which they present a palaeoclimatic reconstruction based on phytolith assemblages from sandy shoreline deposits in the Makgadikgadi Basin, Botswana. While this work highlights a potentially important paleoenvironmental archive in a notably data-poor region, there are several fundamental short-comings in the Burrough et al. work in terms of the calibration of their findings with plant distributions and ecology. Not recognising these limitations in their article, the authors apply palaeoenvironmental indices that are regionally inappropriate, and which we argue in turn render their paleoenvironmental interpretations invalid. With no regionally specific reference collection being established, it may be the misidentification of phytolith morphotypes that has created the paradox that is posed by Burrough et al.
\end{abstract}

Burrough et al. (2012) present a reconstruction of past vegetation change as a response to palaeoclimatic variability based on phytolith assemblages from sandy shoreline deposits in the Makgadikgadi Basin, Botswana. The data presented show diverse assemblages of phytoliths that indicate that the study of these microfossils has potential for the reconstruction past environmental conditions in the region. However, the study as presented contains several fundamental problems, including a lack of consideration of regional environments, plant distributions and ecology. We highlight some of the impacts of these problems, as well as the importance of developing regionally specific reference collections here.

1. Pooideae species are not found within the study region. Burrough et al. claim to have found significant percentages (35$85 \%$ of the short-cell sum) of Pooideae phytoliths in their samples, including samples dating to the late Holocene $(1.4 \pm 0.2 \mathrm{ka})$. There are, however, no Pooideae grasses in Botswana (Field, 1976; Kabelo and Mafokate, 2004; Rutherford et al., 2003, 2012; SANBI, 2003) (Fig. 1). Considering the nature Burrough et al.'s sites, there is always the possibility of long distance fluvial transport, but the primary drainages (i.e. the Okavango) originate in the tropics. Based on the above cited databases (which, it should be noted, contain notably fewer records for Angola and Zambia), no Pooideae are recorded in these catchments, and during the period covered by the Burrough et al. samples (1.4-140 ka) they are unlikely to have grown there (see point 2 ). In those regions with richer datasets, the only parts of southern Africa where Pooideae grasses are found are in upland regions of Zimbabwe, South Africa and Namibia and in the Cape Region, where growing seasons are cooler (mean temperatures of less than $22^{\circ} \mathrm{C}$ ). In all but the Cape, however, $C_{3}$ grasses are still significantly outnumbered by $C_{4}$ grasses (Vogel, 1978; Vogel et al., 1978). In these cool growing season areas, Cordova (2013) found that short cells associated with Pooideae grasses (Group I) make an important part of the diagnostic short cells, but rarely above $20 \%$, with a single outlier at $40 \%$ (Cordova, 2013, figs 11 and 13). All together, the sum of percentages of $C_{3}$ diagnostic short cells (sum of Groups I-IV) never exceeds $60 \%$ (Cordova, 2013, figs 11 and 13). Values above 40\% diagnostic $C_{3}$ short cells occur only in areas with more than $50 \%$ of winter rain or in the mountains of the summer rainfall zone at elevations above $1500 \mathrm{~m}$. In view of the latter, it is very unlikely that the high percentages of $C_{3}$ grasses (i.e., Pooideae) in the record presented by Burrough et al. have occurred in the Kalahari.

Perhaps the most likely explanation for this paradox is the lack of a reliable reference collection for the region, and the possibility of misidentification. Other researchers have encountered similar difficulties, with Kinyanjui (2008) finding 30-80\% "Pooideae" morphotypes in fossil phytolith assemblages from the Solitaire site in the Namib Desert. Further analysis of these samples, however, and the use of high quality photographs of southern African grass phytoliths published by Rossouw (2009) and our own collections, showed some morphotypes produced by some Chloridoideae and Aristidoideae (i.e., Stipagrostis spp.) were most likely misidentified as Pooideae. Problems with phytolith multiplicity (production of many morphotypes within the group) and 


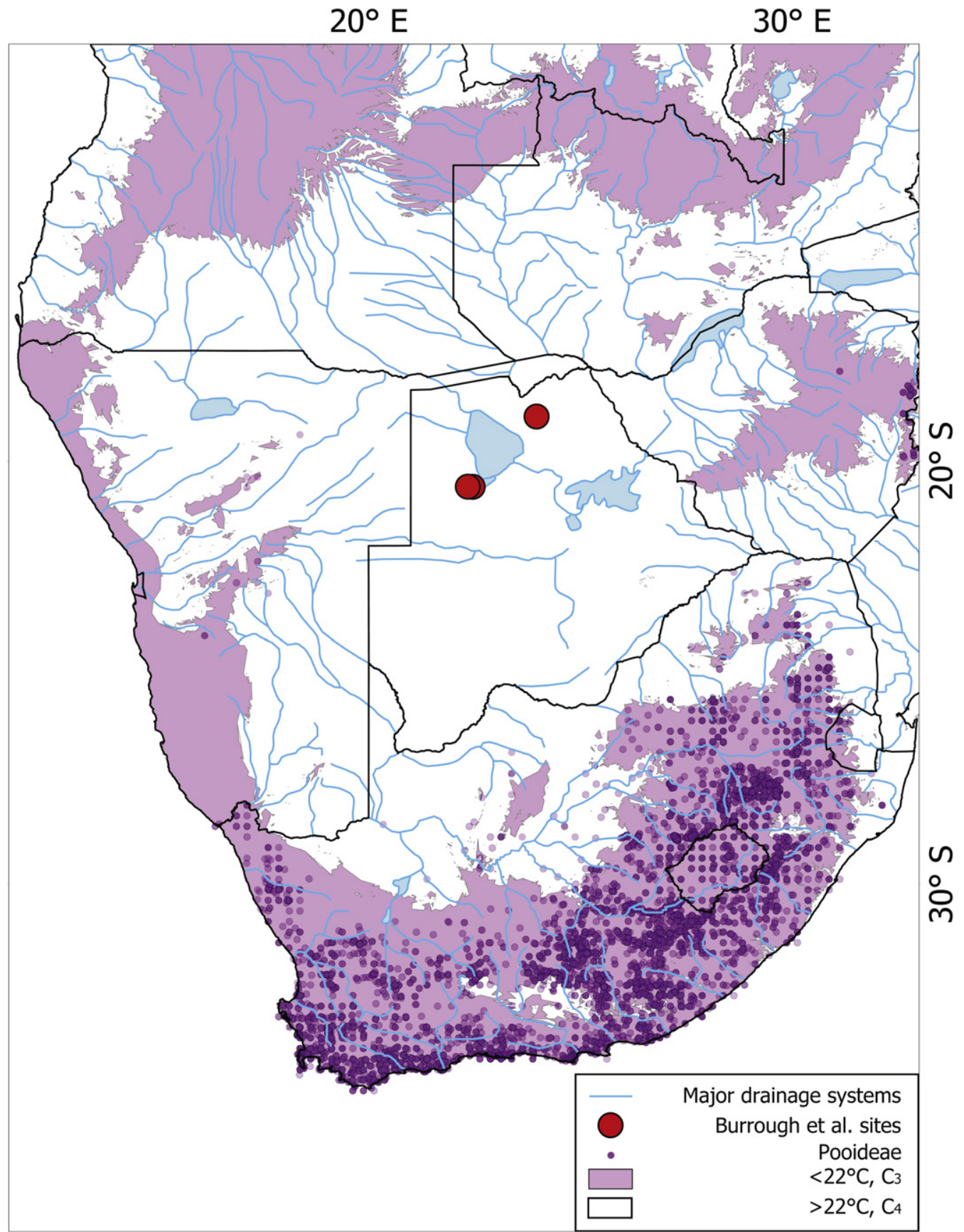

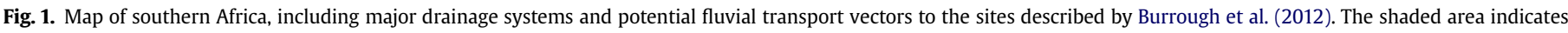

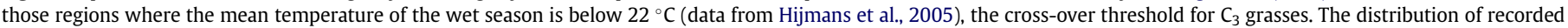
Pooideae grasses is shown (Rutherford et al., 2003; Rutherford et al., 2012; SANBI, 2003), and adheres well to the predicted range of $C_{3}$ grasses.

redundancy (production of morphotypes found in other groups) render Stipagrostis a very difficult taxonomic group to work within phytolith research (Cordova, 2013; Cordova and Scott, 2010). Based on the descriptions of Burrough et al., it is possible that they encountered similar difficulties, and highlights the need for a regionally specific reference as a prerequisite for accurate, reliable phytolith analysis.

2. It is unlikely that Pooideae-type $C_{3}$ grasses existed in the study region in the last $\mathbf{1 4 0 , 0 0 0}$ years. The distribution of Pooideae species adheres to the modelled competitive advantages afforded to these photosynthetic pathways by varying partial pressures of $\mathrm{CO}_{2}$ and mean growing season temperatures
(Collatz et al., 1998; Ehleringer et al., 1997; climate data from Hijmans et al., 2005), whereby with an estimated modern $\mathrm{CO}_{2}$ levels of $\sim 375 \mathrm{ppm}$ (Keeling and Whorf, 2004) the cross-over temperature for $\mathrm{C}_{3}$ grasses is $<22{ }^{\circ} \mathrm{C}$. Calculated by the mean temperature of the wettest quarter (a reliable indicator in such a strongly seasonal region), it is clear that: 1) this is a robust model for predicting the distribution of $C_{3}$ grasses in southern Africa today, including in all probability data-poor regions such as Angola and Zambia (Fig. 1), and 2) that based on past temperature and $\mathrm{CO}_{2}$ estimates, during the early Holocene and last glacial period the distribution would have been even further restricted (Collatz et al., 1998; Ehleringer et al., 1997; Kulongoski and Hilton, 2004; Monnin et al., 2001; Stute and Talma, 1998). 

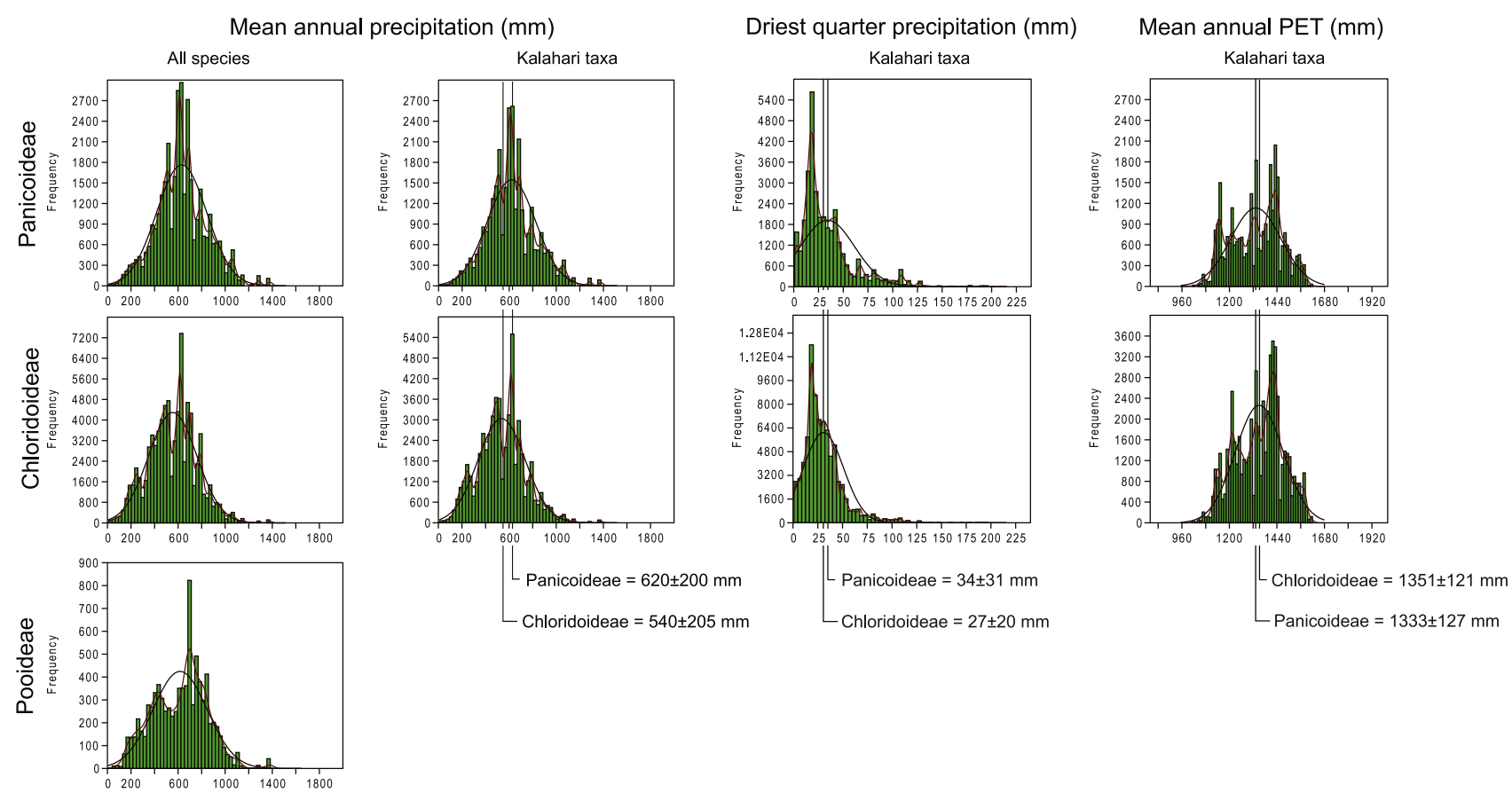

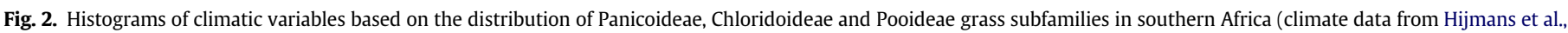

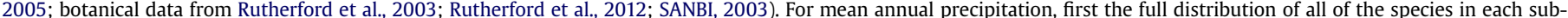

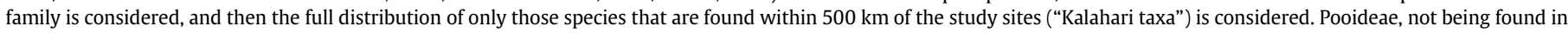

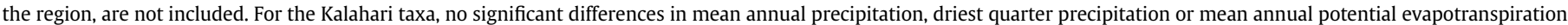
(PET) are found to exist between the Pancoideae and Chloridoideae subfamilies.

These findings and predictions are clearly at odds with the Burrough et al.'s assertion that $C_{3}$ Pooideae grasses were an important part of the vegetation at the study sites at any time during the recent geological past.

3. Considering points 1 and 2 , it is not possible to calculate a "Climatic Index" as the authors have done. Twiss's (1992) "Climatic Index" was created originally for the North American Great Plains, where the amount Pooideae phytoliths have a negative correlation with mid-summer mean temperature (Fredlund and Tieszen, 1997), a situation that can occur in other mid-latitude regions (cf. Twiss, 1992). In East Africa, Barboni et al. (1999) applied this index to areas with strong elevation gradients, where relatively low temperatures during the rainy season may allow some Pooideae to grow. However, in tropical savannas where no $C_{3}$ grasses are found and topographical relief is limited, the application of this index is inappropriate, particularly where these indices have not been tested against the modern temperature and moisture conditions of the region of study (i.e. the Kalahari and surroundings). In the tropical African savanna, the only $C_{3}$ grasses are aquatic (including the Arundinoideae subfamily (i.e., Phragmites) and a few species of the Oryzoideae tribe). The Arundinoideae phytolith shown in the picture in Fig. 2-g of Burrough et al. is, in fact, not produced by Phragmites, or any other Arundinoideae. This type of bilobate is typical of the genus Aristida (see Piperno, 2006, 31, fig. 22), which is a $\mathrm{C}_{4}$ grass relatively common in Botswana is common in overgrazed areas (Field, 1976; Kabelo and Mafokate, 2004).

4. Both in terms of distribution and dominant climatic controls on distribution there is no significant statistical difference between the Chloridoideae and Panicoideae subfamilies in southern Africa. This likely renders the "Aridity Index" calculated by Burrough et al. insensitive in the region. In some parts of the world, including the northern tropics of Africa, there is sufficient spatial differentiation between the Chloridoideae and Panicoideae subfamilies as a function of water availability to calculate a functional "Aridity Index" (Alexandre et al., 1997; Bremond et al., 2005). This partitioning of grass subfamilies is not apparent in the tropics of southern Africa, where Chloridoideae species are more highly diverse in the environments they occupy (Gibbs Russell et al., 1990). Considering observations of Chloridoideae $(n=79,767)$ and Panicoideae $(n=33,748)$ grasses from a number of databases held by the South African National Biodiversity Institute (http://sibis.sanbi.org/faces/DataSources. jsp; Rutherford et al., 2012, 2003; SANBI, 2003), it is apparent, despite inevitable regional sampling biases, that there is no significant difference in the distribution of the subfamilies. We have analysed the subfamily distributions in terms of the climatic variables that best determine 'mesic' vs. 'xeric' conditions (mean annual precipitation, potential evapotranspiration and mean precipitation of the driest quarter; the latter of which is the primary climatic determinant of the subfamilies' distributions according to maximum entropy analyses (Phillips et al., 2006)). From this it is clear that there is no statistical difference between their niches, either when taken as whole subfamilies, or when only those species found within $500 \mathrm{~km}$ of the study sites are considered (Fig. 2). This suggests that the calculated "Aridity Index" is likely to be insensitive in southern Africa.

\section{Acknowledgements}

BMC was funded in part by the European Research Council (ERC) under the European Union's Seventh Framework Programme (FP7/ 2007-2013) grant agreement no. 258657.

\section{References}

Alexandre, A., Meunier, J.-D., Lezine, A.-M., Vincens, A., Schwartz, D., 1997. Phytoliths: indicators of grassland dynamics during the late Holocene in 
intertropical Africa. Palaeogeography, Palaeoclimatology, Palaeoecology 136, 213-229.

Barboni, D., Bonnefille, R., Alexandre, A., Meunier, J.D., 1999. Phytoliths as paleoenvironmental indicators, West Side Middle Awash Valley, Ethiopia. Palaeogeography, Palaeoclimatology, Palaeoecology 152, 87-100.

Bremond, L., Alexandre, A., Peyron, O., Guiot, J., 2005. Grass water stress estimated from phytoliths in West Africa. Journal of Biogeography 32, 311-327.

Burrough, S.L., Breman, E., Dodd, C., 2012. Can phytoliths provide an insight into past vegetation of the Middle Kalahari palaeolakes during the late Quaternary? Journal of Arid Environments 82, 156-164.

Collatz, G.J., Berry, J.A., Clark, J.S., 1998. Effects of climate and atmospheric $\mathrm{CO}_{2}$ partial pressure on the global distribution of $\mathrm{C}_{4}$ grasses: present, past, and future. Oecologia 114, 441-454.

Cordova, C.E., 2013. $C_{3}$ Poaceae and Restionaceae as potential proxies for reconstructing winter rainfall in South Africa. Quaternary International 287, 121-140.

Cordova, C.E., Scott, L., 2010. The potential of Poaceae, Cyperaceae, and Restionaceae phytoliths to reflect past environmental conditions in South Africa. In: Runge, J. (Ed.), Palaeoecology of Africa. CRC Press Taylor and Francis Group, Boca Raton, Florida, pp. 107-133.

Ehleringer, J.R., Cerling, T.E., Helliker, B.R., 1997. $\mathrm{C}_{4}$ photosynthesis, atmospheric $\mathrm{CO}_{2}$, and climate. Oecologia 112, 285-299.

Field, D.I., 1976. A Handbook of Common Grasses in Botswana. Ministry of Agriculture, Gaborone, Botswana.

Fredlund, G.G., Tieszen, L.L., 1997. Calibrating grass phytolith assemblages in climatic terms: application to late Pleistocene assemblages from Kansas and Nebraska. Palaeogeography, Palaeoclimatology, Palaeoecology 136, 199-211.

Gibbs Russell, G.E., Watson, L., Koekemoer, M., Smook, L., Barker, N.P., Anderson, H.M., Dallwitz, M.J., 1990. Grasses of Southern Africa. National Botanical Institute, Pretoria, South Africa.

Hijmans, R., Cameron, S.E., Parra, J.L., Jones, P.G., Jarvis, A., 2005. Very high resolution interpolated climate surfaces for global land areas. International Journal of Climatology 25, 1965-1978.

Kabelo, M., Mafokate, D., 2004. A Checklist of Botswana Grasses. SABONET, Pretoria, South Africa.

Keeling, C.D., Whorf, T.P., 2004. Atmospheric $\mathrm{CO}_{2}$ from Sites in the SIO Air Sampling Network, Trends: a Compendium of Data on Global Change. Carbon Dioxide Information Analysis Center, Oak Ridge National Laboratory, U.S. Department of Energy, Oak Ridge, Tenn., U.S.A.

Kinyanjui, R., 2008. Pollen and Phytolith Analysis of Fossil Hyrax (Procavia Capensis) Middens from Namibia. Department of Environmental and Geographical Sciences. University of Cape Town, Rondebosch.

Kulongoski, J.T., Hilton, D.R., 2004. Climate variability in the Botswana Kalahari from the late Pleistocene to the present day. Geophysical Research Letters 31.

Monnin, E., Indermühle, A., Dällenbach, A., Flückiger, J., Stauffer, B., Stocker, T.F. Raynaud, D., Barnola, J.-M., 2001. Atmospheric $\mathrm{CO}_{2}$ concentrations over the last glacial termination. Science 291, 112-114.

Phillips, S.J., Anderson, R.P., Schapire, R.E., 2006. Maximum entropy modeling of species geographic distributions. Ecological Modelling 190, 231-259.

Piperno, D.R., 2006. Phytoliths: a Comprehensive Guide for Archaeologists and Paleoecologists. Altamira Press, Lanham, Maryland.

Rossouw, L., 2009. The Application of Fossil Grass-phytolith Analysis in the Reconstruction of Cainozoic Environments in the South African Interior. Department of Plant Sciences. University of the Free State, Bloemfontein.
Rutherford, M.C., Mucina, L., Powrie, L.W., 2012. The South African National Vegetation Database: history, development, applications, problems and future. South African Journal of Science 108. http://dx.doi.org/10.4102/sajs.v108i1/2.629.

Rutherford, M.C., Powrie, L.W., Midgley, G.F., 2003. ACKDAT: a digital spatial database of distributions of South African plant species and species assemblages. South African Journal of Botany 69, 99-104.

SANBI, 2003. PRECIS (National Herbarium Pretoria (PRE) Computerized Information System) Database.

Stute, M., Talma, A.S., 1998. Glacial Temperatures and Moisture Transport Regimes Reconstructed from Noble Gas and $\delta^{18} \mathrm{O}$, Stampriet Aquifer, Namibia, Isotope Techniques in the Study of Past and Current Environmental Changes in the Hydrosphere and the Atmosphere. IAEA Vienna Symposium 1997, Vienna, pp. 307-328.

Twiss, P.C., 1992. Predicted world distribution of $C_{3}$ and $C_{4}$ grass phytoliths. In: Rapp, G., Mulholland, S.C. (Eds.), Phytolith Systematics, pp. 113-128.

Vogel, J.C., 1978. Isotopic assessment of dietary habits of ungulates. South African Journal of Science 74, 298-301.

Vogel, J.C., Fuls, A., Ellis, R.P., 1978. The geographical distribution of Kranz grasses in South Africa. South African Journal of Science 74, 209-215.

Department of Geography, Oklahoma State University, Stillwater, OK

74078, USA

B.M. Chase

Institut des Sciences de l'Evolution de Montpellier (ISEM), UM2, CNRS, IRD, Place Eugène Bataillon cc 061, 34095 Montpellier cedex 5, France

Department of Archaeology, History, Culture and Religion, University of Bergen, Postbox 7805, 5020 Bergen, Norway

G.F. Smith

Biosystematics Research and Biodiversity Collections, South African National Biodiversity Institute, Private Bag X101, Pretoria 0001, South Africa

Schweickerdt Herbarium, Department of Botany, University of Pretoria, Pretoria 0002, South Africa

Centre for Functional Ecology, Departamento de Ciências da Vida, Universidade de Coimbra, 3001-455 Coimbra, Portugal

* Corresponding author. Tel.: +1 4057449174.

E-mail addresses: cordova@okstate.edu, carlos.cordova@okstate.edu (C.E. Cordova) 